REFLECTIONS:

NEUROLOGY AND

THE HUMANITIES

Section Editor

Anne W. McCammon,

MD, FAAN

\title{
What is the value of a neurologist?
}

Pushpa Narayanaswami, MD

Correspondence to Dr. Narayanaswami: pnarayan@bidmc.harvard.edu
I open my e-mails, only to see yet another admonishment from the hospital administration. I have not checked enough boxes on the electronic health record, and therefore have not met criteria for meaningful use. I wonder: is this what taking care of my patients boils down to?

It was Friday morning, and I awoke anxious, reluctant to confront the day. Facing me was the usual busy schedule of EMGs and clinic patients. Nothing out of the ordinary, yet I was anxious because I knew that I would have to break the news to Ms. S.A., a 50-yearold woman, that she had amyotrophic lateral sclerosis (ALS). I had worked her in urgently a week prior at a colleague's request. As I listened to her history and examined her, automatic thoughts, the product of years of training and experience, ran through my mind and crystallized into a diagnosis: clinically probable ALS. I sifted through her history and examination and perused her cervical spine MRI for anything that would tell me otherwise. Zebra diagnoses danced through my mind: could she have polyglucosan body disease, hexosaminidase deficiency, or a pure motor variant of syringomyelia? Was she Ashkenazi Jew? I ordered bloodwork and a brain MRI and worked her into my EMG schedule the following Friday.

Today was that Friday, and she was the last patient of the day. As expected, bloodwork results were unremarkable and brain MRI showed no abnormalities to explain her clinical picture. She came in, anxious, hoping that she had a treatable condition. The EMG provided no alternative diagnosis.

I discussed all her results and showed her the MRI. I gave her the scientific explanation: that her symptoms pointed towards an affliction of her motor neurons. Her husband had researched her symptoms on the Internet and asked if she could have multifocal motor neuropathy. I spent some time explaining why her symptoms were not consistent with that diagnosis.

She was devastated when she realized that I was indeed telling her that she most likely has ALS. She asked me what she should tell her children, ages 13 and 17; what her life expectancy was; and how the disease would progress. She cried. The discussion changed from the scientific to the emotional. I reassured her, as much as one can reassure when delivering a diagnosis of ALS. I held her hand.
Her husband asked about riluzole. The scientific discussion again: dose, side effects, monitoring. She asked when the disease would spread to her legs. And affect her swallowing. She cried again and said she was hoping for an alternative diagnosis. I urged a second opinion so she would not have any doubts. She said she would prove me wrong. Then the practical discussion: what next? Occupational therapy, prescriptions, follow-up appointments. I hugged her, and told her I would walk through this with her. Her husband cried. He requested that I call every so often to check on her.

I was emotionally drained. I made a note on my calendar to call her every week, and billed a level 5 evaluation and management (E and $\mathrm{M}$ ) visit code. And wondered what code covered the time and the emotions I had spent soothing, comforting, consoling. Is it the one that states "over $50 \%$ of this 40 -minute visit was spent in counseling and coordination of care?" Is there a code for telephone calls to ask how she is doing and help her feel less alone and afraid?

Mr. S.L. was in his mid-40s when I diagnosed him with ALS. His wife accompanied him to the visits, and I saw him go from being ambulatory to wheelchairbound; from conversant to barely comprehensible because of dysarthria. His wife called me, guilt-ridden about placing him in a care facility. She had to work to sustain the family, and help was not available. I just listened, let her talk, and reassured her that she knew what was best for her husband and her family. They brought their 3 sons in to talk to me. The oldest was 16 and deeply involved with his father's care. The youngest boy was 7 , scared and not quite understanding the situation. The middle child, about 12 , shut himself off, would not talk about his father or spend time with him. I spent an hour and a half explaining, letting them talk, probing their fears, and answering questions. I gave them my cell phone number to call or text me any time they were scared or had a question. I did not bill for that visit, nor do I know of a code for comforting the children of a patient with ALS.

Mr. E.N. was in his mid-50s, very active, and a physical fitness freak, but he smoked. He had dermatomyositis, and I was worried about an underlying cancer. Indeed, he had lung cancer, stage III at diagnosis. He was one of the most positive people I have had

Listen to Dr. Narayanaswami read this story, available exclusively on Neurology ${ }^{\circledR}$ for the iPad ${ }^{\circledR}$. 
the honor to know. He fought the disease with all his strength, never giving up even though he knew the inevitable. A long-term relationship that was leading to marriage fell through when he fell ill. He bounced back. He developed a pulmonary embolism, pancytopenia and diarrhea from chemotherapy, and brain metastases. I watched his expectations shift with the ravaging effects of the relentlessly progressing cancer, a phenomenon that oncologists recognize as goal resetting. Initially, his plan was to go back to exercising at his original pace. Then, he was satisfied that he could walk up and down the hill outside his home without tiring. Finally, he was happy that he could go out in his wheelchair and enjoy a day at the museum.

I went to see him when he was admitted to the hospital with infections or chemotherapy side effects. I did not do a formal neurology consultation, but I always looked through his chart and performed a neurologic examination to ascertain that he was stable. I did not bill for those visits. I sat with him and we talked. About life. And death. I do not know an E and M code for compassion. I would not bill for it even if there were one. But from his indomitable spirit, I learned the true meaning of courage in the face of all adversity.

Mrs. P.S. is a Jewish widow in her 80s whom I have followed for the last 7 years, primarily for painful diabetic neuropathy. Seeing her name on my schedule brings a smile to my face. I have diagnosed and treated her restless legs, benign positional vertigo, and carpal tunnel syndrome. Not long ago, she called me with foot pain, thinking it was her neuropathy, and after I coaxed some details out of her, I suggested that it was more likely to be gout, and sent her to her primary care physician. She still grieves for her husband, the love of her life. She asks me if I believe in reincarnation and tells me that she is certain that $\mathrm{I}$, a Hindu, was her daughter in a previous life. Her visits are long. There are several medical issues to address. I think she has early dementia. She does not like to give me details. So I am digging for information, cajoling her to have investigations done. I have to choose the tests carefully and prioritize what is most important, or they will never get done. I bill the usual level $4 \mathrm{E}$ and M. My notes document all the diagnoses and the plan of management. But they do not reflect our long conversations or our friendship. I do not know an $\mathrm{E}$ and $\mathrm{M}$ code for friendship and I would not bill for it even if there were one.

Mr. P.M. is in his 80s, of Irish descent, who comes in to see me with his wife. He has a multitude of medical problems including high creatine kinase, which I have investigated, and have opted to follow closely instead of proceeding with a muscle biopsy. In order to do a muscle biopsy, I would have to stop his anticoagulants, with resultant risk of stroke, and I do not believe that the potential benefit justifies the risk. We have discussed this. I examine him to make sure his muscle strength is normal. And then we chat. He complains that I side with his wife and he is outnumbered. He flirts with me, eyes twinkling merrily. I tell him he kissed the Blarney Stone. I assure him he is strong enough, agile enough, to take his wife dancing. She bemoans his two left feet, and tells me he's probably the only Irishman who cannot dance to save his life. I bill a level $3 \mathrm{E}$ and $\mathrm{M}$ visit. I do not know an $\mathrm{E}$ and $\mathrm{M}$ code for humorous empathy. I would not bill for it even if there were one.

And then, reality sets in. It is again time to check off all the boxes for meaningful use and Physician Quality Reporting System, familiar to us as PQRS, on my electronic health record. I should make certain there is a problem list, tobacco use is documented, and medication reconciliation is completed. I am warned that there will be more boxes to check in the coming years, whether relevant to my patient or not, in order to avoid an adjustment, a euphemistic term for penalty. I read about the impending end of fee-for-service and about the value-based payment systems and patient-centered medical homes that are the payment models of the future.

I understand that there is an urgent need to demonstrate my value, and the value of my profession of neurology, but I wonder: upon whom did medical care center before the catch phrase patient-centered was introduced? I read that patient satisfaction ratings of me and my service will be posted online so that other patients can decide if they want to see me. Not one of patients I have described has filled out a satisfaction survey. Are they not satisfied with me? How do I prove that coming to see me adds value to their medical care?

As health care struggles with rising costs, the impetus to prove value, defined as health care outcomes per dollar spent, increases. However, outcome measures are not easy to define in neurology, where many neurologic disorders do not yet have cures, and even improvement may not be an option. Consequently, value is not easy to measure. Quality measures ensure that care provided is consistent with established standards. But what is the value of the care that we provide to our patients? These patient stories resonate with each of us: they may be patients with multiple sclerosis, Alzheimer disease, Parkinson disease, epilepsy, or stroke. We walk with our patients and their families through their illness, providing support and comfort, to alleviate and soothe even if we are unable to heal. How do we measure this? How do we prove our value? Is there a box on the electronic medical record to check when we listen to our patients, talk to them, and hold their hands? Or is this of no value?

\section{ACKNOWLEDGMENT}

In honor of my father, Dr. V. Narayanaswami, who inspired me when I was 3 years old to become a physician, and my mother, Janaki Narayanaswami, who helped me realize that goal. 


\title{
Neurology
}

\author{
What is the value of a neurologist? \\ Pushpa Narayanaswami \\ Neurology 2015;84;209-210 \\ DOI 10.1212/WNL.0000000000001139
}

This information is current as of January 12, 2015

\section{Updated Information \&} Services

\section{Citations}

\section{Subspecialty Collections}

Permissions \& Licensing

Reprints including high resolution figures, can be found at: http://n.neurology.org/content/84/2/209.full

This article has been cited by 1 HighWire-hosted articles: http://n.neurology.org/content/84/2/209.full\#\#otherarticles

This article, along with others on similar topics, appears in the following collection(s): All Clinical Neurology http://n.neurology.org/cgi/collection/all_clinical_neurology

Information about reproducing this article in parts (figures,tables) or in its entirety can be found online at:

http://www.neurology.org/about/about_the_journal\#permissions

Information about ordering reprints can be found online: http://n.neurology.org/subscribers/advertise

Neurology ${ }^{\circledR}$ is the official journal of the American Academy of Neurology. Published continuously since 1951, it is now a weekly with 48 issues per year. Copyright () 2015 American Academy of Neurology. All rights reserved. Print ISSN: 0028-3878. Online ISSN: 1526-632X.

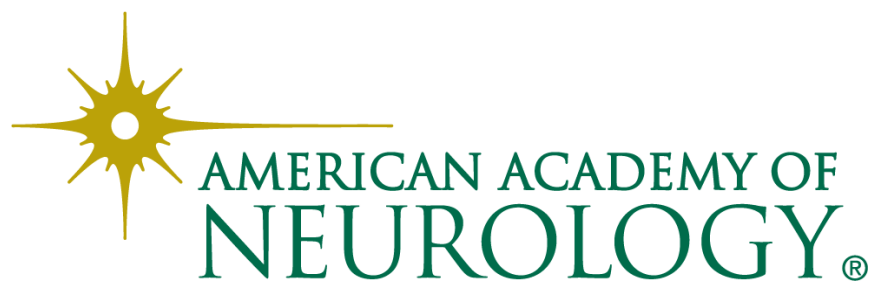

